\title{
Effects of nilotinib on regulatory T cells: the dose matters
}

Fei Fei ${ }^{1 \dagger}$, Yingzhe $\mathrm{Yu}^{1 \dagger}$, Anita Schmitt ${ }^{1,4}$, Markus T Rojewski ${ }^{2}$, Baoan $\mathrm{Chen}^{3}$, Jochen Greiner ${ }^{1}$, Marlies Götz ${ }^{1}$, Donald Bunjes ${ }^{1}$, Michael Schmitt ${ }^{1,4^{*}}$

\begin{abstract}
Background: Nilotinib is a tyrosine kinase inhibitor with high target specificity. Here, we characterized the effects of nilotinib for the first time on $\mathrm{CD}^{+} \mathrm{CD} 25^{+}$regulatory $T$ cells (Tregs) which regulate anti-tumor/leukemia immune responses.
\end{abstract}

Design and Methods: Carboxyfluorescein diacetate succinimidyl ester (CFSE) and 5-bromo-2-deoxy -uridine (BrdU) were used to assess the proliferation and cell cycle distribution of Tregs. The expression of the transcription factor forkhead box P3 (FoxP3) and the glucocorticoid-induced tumor necrosis factor receptor (GITR) were measured by flow cytometry. Western blotting analysis was used to detect the effects of nilotinib on the signal transduction cascade of T-cell receptor (TCR) in Tregs.

Results: Nilotinib inhibited the proliferation and suppressive capacity of Tregs in a dose-dependent manner. However, the production of cytokines secreted by Tregs and $C D 4^{+} \mathrm{CD} 25^{-} \mathrm{T}$ cells was only inhibited at high concentrations of nilotinib exceeding the mean therapeutic serum concentrations of the drug in patients. Only high doses of nilotinib arrested both Tregs and $C D 4^{+} C D 25^{-} T$ cells in the $G_{0} / G_{1}$ phase and down-regulated the expression of FoxP3 and GITR. In western blotting analysis, nilotinib did not show significant inhibitory effects on TCR signaling events in Tregs and $C D 4^{+} \mathrm{CD} 25^{-} \mathrm{T}$ cells.

Conclusions: These findings indicate that nilotinib does not hamper the function of Tregs at clinical relevant doses, while long-term administration of nilotinib still needs to be investigated.

\section{Introduction}

Nilotinib (AMN107, Tasigna; Novartis Pharma, Basel, Switzerland) is a new, orally active, selective inhibitor of the ABL/BCR-ABL, CSF-1R, DDR, KIT, and PDGFR tyrosine kinases, that is more potent against chronic myeloid leukemia (CML) cells in vitro than is imatinib. Like imatinib, nilotinib acts through competitive inhibition at the ATP-binding site of BCR-ABL, leading to the inhibition of tyrosine phosphorylation of proteins that are involved in the intracellular signal transduction mediated BCR-ABL. Nilotinib has a higher binding affinity and selectivity for the ABL kinase than does imatinib, which translates into 20 - to 50 -fold greater inhibitory activity than imatinib in imatinib-sensitive CML cells and 3- to 7-times the activity in imatinib-

\footnotetext{
* Correspondence: michael.schmitt@med.uni-rostock.de

+ Contributed equally

'Department of Internal Medicine III, University of UIm, 89081 UIm, Germany
}

resistant cell lines with mutant ABL kinases [1-5]. Results from a phase I dose escalation study performed in patients with imatinib-resistant CML and Philadelphia $(\mathrm{Ph})$ chromosome-positive acute lymphoblastic leukemia (ALL) indicated that nilotinib produced significant hematologic and cytogenetic responses in all phases of CML [2]. Furthermore, $400 \mathrm{mg}$ nilotinib was administered orally twice daily, proved to be very active and safe in phase II study of patients with chronic phase CML and accelerated-phase CML post-imatinib resistance and intolerance [6,7]. Now, clinical trials with nilotinib are ongoing in patients with imatinib-resistant or imatinib-intolerant accelerated-phase CML and Phpositive ALL $[7,8]$.

Naturally arising $\mathrm{CD} 44^{+} \mathrm{CD} 25^{+}$regulatory $\mathrm{T}$ cells (Tregs) have the potential to suppress aberrant immune responses and to regulate peripheral $\mathrm{T}$-cell homeostasis [9]. Tregs play a crucial role in both the induction and maintenance of tolerance. This active immune 
regulation may contribute not only to the control of immune responses to self-antigens, thereby preventing autoimmune diseases, but also the control of responses to non-self molecules in adaptive immunity. Numerous experimental and clinical studies indicate that manipulating the balance between regulatory and effector $\mathrm{T}$ cells is an effective strategy to control immune responsiveness after transplantation. Therefore a better understanding of regulatory $\mathrm{T}$ cells biology is essential for exploiting this strategy to clinical therapy [10].

There is evidence that imatinib and dasatinib have inhibitory effects on immune reconstitution and $\mathrm{T}$ cell proliferation and function [11-15]. Furthermore, nilotinib was shown to have an inhibitory effect on $\mathrm{CD}^{+} \mathrm{T}$ cells in vitro [16], however little is known about its effects on Tregs [17]. Therefore, we wondered to what extent and by which mechanisms nilotinib affects the immune system, particularly for Tregs. In this study, we examined the effects of nilotinib on both Tregs and CD ${ }^{+} \mathrm{CD} 25^{-} \mathrm{T}$ cells. We indicate that nilotinib similarly inhibits proliferation and function of Tregs as well as $\mathrm{CD} 4^{+} \mathrm{CD} 25^{-} \mathrm{T}$ cells only at high concentrations greater than $10 \mu \mathrm{M}$ nilotinib which exceeds the therapeutic range achieved with current standard dosing schedules.

\section{Design and Methods}

\section{Nilotinib, imatinib and dasatinib}

Nilotinib and imatinib were provided by Novartis Pharmaceuticals, Basel, Switzerland. Dasatinib was purchased from Bristol-Myers Squibb, New York, NY, USA and stored in aliquots at $-20^{\circ} \mathrm{C}$ as $10 \mathrm{mM}$ stock solution in DMSO.

\section{Cell isolation and culture}

Peripheral blood mononuclear cells (PBMCs) were isolated by Ficoll-Biocoll Separation Solution (Biochrom, Berlin, Germany) as described previously [18]. CD4 ${ }^{+} \mathrm{CD} 25^{+} \mathrm{T}$ cells and $\mathrm{CD} 4{ }^{+} \mathrm{CD} 25^{-} \mathrm{T}$ cells were selected from the total PBMCs using $\mathrm{CD} 4{ }^{+} \mathrm{CD} 25^{+}$regulatory $\mathrm{T}$ cell isolation kit (Miltenyi Biotec, Bergisch Gladbach, Germany), according to the manufacturer's instruction. This procedure led to the complete positive selection of $\mathrm{CD} 4{ }^{+} \mathrm{CD} 25^{+} \mathrm{T}$ cells (purity $\geq 90 \%$ ), and negative depletion of $\mathrm{CD} 4^{+} \mathrm{CD} 25^{-} \mathrm{T}$ cells, as measured by flow cytometry (FACSan, Becton Dickinson, Franklin Lake, NJ, USA). Cells were cultured in RPMI 1640 (Biochrom AG, Berlin, Germany) supplemented with $10 \%$ human AB serum (Germany Red Cross Blood Center, Ulm, Germany), $2 \mathrm{mM}$ L-glutamine and 100 units/ml penicillin-streptomycin (Invitrogen Gibco, Grand Island, USA).

\section{CFSE-based cell proliferation}

Isolated $\mathrm{CD} 4{ }^{+} \mathrm{CD} 25^{+} \mathrm{T}$ cells $\left(1 \times 10^{6} / \mathrm{ml}\right)$ and $\mathrm{CD} 4$ ${ }^{+} \mathrm{CD} 25^{-} \mathrm{T}$ cells $\left(1 \times 10^{6} / \mathrm{ml}\right)$ were labeled with $0.5 \mu \mathrm{M}$ vital dye carboxyfluorescein diacetate succinimidyl ester (CFSE, Invitrogen Gibco, Grand Island, USA) just before stimulation. Labeled $\mathrm{CD} 4{ }^{+} \mathrm{CD} 25^{+} \mathrm{T}$ cells $\left(1 \times 10^{5} /\right.$ well $)$ or $\mathrm{CD}^{+} \mathrm{CD} 25^{-} \mathrm{T}$ cells $\left(1 \times 10^{5} /\right.$ well $)$ were stimulated with anti-CD3 (OKT3; eBioscience, San Diego, CA, USA) and $2 \mu \mathrm{g} / \mathrm{ml}$ soluble anti-CD28 (CD28.2, BD Pharmingen $^{\mathrm{Tm}}$, Heidelberg, Germany). 300 units/ml IL-2 was used to expand $\mathrm{CD} 4^{+} \mathrm{CD} 25^{+} \mathrm{T}$ cells. After 4 days of stimulation, cell division was monitored by levels of CFSE dilution. Unstimulated $\mathrm{T}$ cells served as negative control in all experiments.

\section{Suppression assay}

CD $4+\mathrm{CD}_{2} 5^{+} \mathrm{T}$ cells were incubated for 4 days with $\mathrm{CFSE}^{+}$-labeled CD4+CD25- $\mathrm{T}$ cells, with each population $5 \times 10^{4}$ cells in the presence of anti-CD3 and antiCD28. In some experiments, CD $4{ }^{+} \mathrm{CD} 25^{+} \mathrm{T}$ cells were first incubated with nilotinib overnight, then the cells were washed for three times and co-cultured with CFSE ${ }^{+}$-labeled $\mathrm{CD} 4{ }^{+} \mathrm{CD} 25^{-} \mathrm{T}$ cells as a ratio of $1: 1$ as mentioned above.

\section{Apoptosis assay}

$\mathrm{CD} 4^{+} \mathrm{CD} 25^{+} \mathrm{T}$ cells and $\mathrm{CD} 4^{+} \mathrm{CD} 25^{-} \mathrm{T}$ cells were treated with nilotinib for $48 \mathrm{~h}$. Cells were harvested and stained with Annexin $\mathrm{V}^{*}$ fluorescein isothiocyanate (FITC) and propidium iodide (PI) (Annexin V*FITC apoptosis detection kit I; BD Pharmingen ${ }^{\mathrm{TM}}$, Heidelberg, Germany). Apoptotic cells were defined by flow cytometry as Annexin V positive and PI-negative cells.

\section{Cell cycle analysis}

An indirect 5-bromo-2-deoxyuridine (BrdU)-FITC flow kit (BD Pharmingen ${ }^{\mathrm{Tm}}$, Heidelberg, Germany) was used to determine the cycle kinetics of $\mathrm{CD} 4{ }^{+} \mathrm{CD} 25^{+} \mathrm{T}$ cells and $\mathrm{CD} 4{ }^{+} \mathrm{CD} 25^{-} \mathrm{T}$ cells, and to measure the incorporation of BrdU into the DNA of proliferating cells. CD4 ${ }^{+} \mathrm{CD} 25^{+} \mathrm{T}$ cells or $\mathrm{CD} 4{ }^{+} \mathrm{CD} 25^{-} \mathrm{T}$ cells were treated with different concentrations of nilotinib as indicated for 4 days. Cells were harvested and measured according to the manufacturer's instruction.

\section{Cytokine analysis}

$\mathrm{CD} 4{ }^{+} \mathrm{CD} 25^{+} \mathrm{T}$ cells and $\mathrm{CD} 4^{+} \mathrm{CD} 25^{-} \mathrm{T}$ cells were stimulated with anti-CD3, anti-CD28 and IL-2 in the presence or absence of $25 \mu \mathrm{M}$ nilotinib. After 4 days incubation, supernatants were collected and analyzed for cytokines according to the instruction of Proteome Profiler Array (R\&D Systems, Minneapolis, MN, USA).

\section{Flow cytometry}

Cells were phenotyped by 4- or 5- color Abs and measured by flow cytometry as described previously [18]. The following conjugated Abs were used: CD4* 
fluorescein isothiocyanate (FITC), CD4*phycoerythrinCyanine 7 (PE-Cy7), CD25* phycoerythrin-Cyanine 5 (PE-Cy5), CD25* Allophycocyanin (APC) (BD Pharmingen $^{\mathrm{Tm}}$, Heidelberg, Germany), transcription factor forkhead box P3 (FoxP3)* phycoerythrin (PE) (PCH 101; eBioscience, San Diego, CA), and glucocorticoid-induced tumor necrosis factor receptor (GITR)* PE (R\&D Systems, Minneapolis, MN, USA),

\section{Western blotting}

$\mathrm{CD} 4^{+} \mathrm{CD} 25^{+} \mathrm{T}$ cells, CD $4^{+} \mathrm{CD} 25^{-} \mathrm{T}$ cells or Jurkat $\mathrm{T}$ cells $\left(1 \times 10^{6}\right.$ cells/well $)$ were treated with different concentrations of imatinib, nilotinib or dasatinib for 1 hour and stimulated with anti-CD3/CD28 for 15 minutes. Western blotting analysis was performed as previously described [18] by using the following antibodies: phospho-Lck, Lck, phospho-ZAP-70, ZAP-70, phospho-p44/ 42 MAP kinase, p44/42 MAP kinase, phospho-Akt, Akt, src, phospho-src family (Tyr416), non-phospho-src (Tyr416), phospho-src (Tyr527), non-phospho-src (Tyr527), phospho-NF- $\kappa$ B p65 (Ser536)(93H1) and NF$\kappa \mathrm{B}$ p65 from Cell Signaling Technology, USA and antiActin C-11 (Santa Cruz Biotechnology, Heidelberg, Germany) to confirm equal protein loading.

\section{Statistical analysis}

Statistical analysis was performed with SPSS software. Data were presented as mean \pm standard deviation (SD). Statistical significance of differences between groups was evaluated using one-way-ANOVA (post hoc Scheffe test). The value of $P<.05$ was considered to be statistically significant.

\section{Results}

In phase I clinical studies, at the steady-state, mean serum levels of nilotinib were: $1.0 \mu \mathrm{M}$ at $400 \mathrm{mg}$ once daily, $1.7 \mu \mathrm{M}$ at $400 \mathrm{mg}$ twice daily, and $2.3 \mu \mathrm{M}$ at 600 mg twice daily; at $400 \mathrm{mg}$ twice daily, the dose selected for phase II studies, steady state mean serum peak levels of drug were $3.6 \mu \mathrm{M}$ [2]. Based upon this, to include the clinically relevant dose range of nilotinib, all assays described in this manuscript were performed at concentrations between 1 and $25 \mu \mathrm{M}$.

\section{Nilotinib inhibits the proliferation of $\mathrm{CD} 4{ }^{+} \mathrm{CD} 25^{+} \mathrm{T}$ cells and $\mathrm{CD}^{+} \mathrm{CD} 25^{-} \mathrm{T}$ cells in a dose-dependent manner} Human $\mathrm{CD} 4{ }^{+} \mathrm{CD} 25^{+} \mathrm{T}$ cells could be expanded by antiCD3, anti-CD28 and high doses of IL-2 (Figure 1A and $1 C)$, in accordance with previous findings $[19,20]$. Addition of nilotinib inhibited the proliferation of both CD4 ${ }^{+} \mathrm{CD} 25^{+} \mathrm{T}$ cells (Figure $1 \mathrm{~A}$ and $1 \mathrm{C}$ ) and $\mathrm{CD} 4{ }^{+} \mathrm{CD} 25^{-} \mathrm{T}$ cells (Figure $1 \mathrm{~B}$ and $1 \mathrm{D}$ ) in a dose-dependent manner as shown in Figure 1. The effect was significant at concentrations of nilotinib greater than $10 \mu \mathrm{M}$ and $25 \mu \mathrm{M}$ for
$\mathrm{CD} 4{ }^{+} \mathrm{CD} 25^{+} \mathrm{T}$ cells and $\mathrm{CD} 4^{+} \mathrm{CD} 25^{-} \mathrm{T}$ cells respectively. However the concentrations exceeded the mean serum levels achieved in patients to whom nilotinib was administered.

\section{Nilotinib has no inhibitory effect on the suppressive capacity of $\mathrm{CD}^{+} \mathrm{CD} 25^{+} \mathrm{T}$ cells}

Our dose-dependent proliferation assays indicated that nilotinib at a concentration between $1-25 \mu \mathrm{M}$ is suboptimal for the inhibition of the $\mathrm{CD} 4{ }^{+} \mathrm{CD} 25^{+} \mathrm{T}$ cells and $\mathrm{CD} 4{ }^{+} \mathrm{CD} 25^{-} \mathrm{T}$ cells. Therefore, the use of these concentrations of nilotinib would allow us to assess an additional inhibition of $\mathrm{CD} 4^{+} \mathrm{CD} 25^{-} \mathrm{T}$ cells by adding CD4 ${ }^{+} \mathrm{CD} 25^{+} \mathrm{T}$ cells. We observed that adding nilotinib to the co-cultures led to an additional inhibition of $\mathrm{CD} 4^{+} \mathrm{CD} 25^{-}$ $\mathrm{T}$ cells proliferation (Figure $2 \mathrm{~A}$ ) which might be the reason that nilotinib had a inhibitory effect on CD $4^{+} \mathrm{CD} 25^{-}$ $\mathrm{T}$ cells. Nilotinib at a concentration up to $25 \mu \mathrm{M}$ did not hamper the suppressive capacity of $\mathrm{CD} 4{ }^{+} \mathrm{CD} 25^{+} \mathrm{T}$ cell.

To further investigate the effect of nilotinib on the suppressive capacity of $\mathrm{CD} 4{ }^{+} \mathrm{CD} 25^{+} \mathrm{T}$ cells, $\mathrm{CD} 4^{+} \mathrm{CD} 25$ $+\mathrm{T}$ cells were first incubated with or without different concentrations of nilotinib overnight in the presence of IL-2. Then, cells were washed three times to remove nilotinib and co-cultured together with $\mathrm{CFSE}^{+}$-labeled $\mathrm{CD} 4{ }^{+} \mathrm{CD} 25^{-} \mathrm{T}$ cells at a 1:1 ratio. After four days incubation, the proliferation of $\mathrm{CD} 4^{+} \mathrm{CD} 25^{-} \mathrm{T}$ cells was measured by flow cytometry. To clarify whether $\mathrm{CD} 4{ }^{+} \mathrm{CD} 25$ ${ }^{+} \mathrm{T}$ cells viability could be reduced by overnight incubation, we first measured the viability of $\mathrm{CD} 4{ }^{+} \mathrm{CD} 25^{+} \mathrm{T}$ cells and $\mathrm{CD} 4^{+} \mathrm{CD} 25^{-} \mathrm{T}$ cells after overnight incubation by staining cells with Annexin V*FITC and 7-AAD. Nilotinib did not reduce the viability of $\mathrm{CD} 4{ }^{+} \mathrm{CD} 25^{+} \mathrm{T}$ cells and $\mathrm{CD} 4^{+} \mathrm{CD} 25^{-} \mathrm{T}$ cells after pre-incubation overnight (data not shown). As shown in Figure 2B, nilotinib inhibited the suppressive capacity of $\mathrm{CD} 4{ }^{+} \mathrm{CD} 25^{+} \mathrm{T}$ cells at concentrations higher than $5 \mu \mathrm{M}$.

\section{Nilotinib does not induce apoptosis of $\mathrm{CD}^{+} \mathrm{CD} 25^{+} \mathrm{T}$ cells or $\mathrm{CD}^{+}{ }^{+} \mathrm{CD} 25^{-} \mathrm{T}$ cells}

To assess whether nilotinib might induce apoptosis or cell death in $\mathrm{CD} 4^{+} \mathrm{CD} 25^{+} \mathrm{T}$ cells and $\mathrm{CD} 4^{+} \mathrm{CD} 25^{-} \mathrm{T}$ cells. We incubated $\mathrm{CD} 4^{+} \mathrm{CD} 25^{+} \mathrm{T}$ cells or $\mathrm{CD} 4^{+} \mathrm{CD} 25^{-}$ $\mathrm{T}$ cells with different concentrations of nilotinib as indicated for 4 days and measured apoptosis and cell death by Annexin $\mathrm{V}^{*}$ FITC and PI staining. The percentage of Annexin V*FITC-positive and PI-negative events of CD4 ${ }^{+} \mathrm{CD} 25^{+} \mathrm{T}$ cells, which corresponds to apoptotic cells, remained between $27.75 \pm 14.05 \%$ to $42.05 \pm 6.09 \%$ compared with $44.53 \pm 8.60 \%$ of untreated cells $(P>$ $.05)$ (Figure 3). The percentage of apoptotic CD4 ${ }^{+} \mathrm{CD} 25^{-}$ $\mathrm{T}$ cells remained between $16.80 \pm 4.70 \%$ to $22.15 \pm$ $7.41 \%$ compared with $23.18 \pm 8.20 \%$ of untreated cells. According to apoptosis assay, $\mathrm{CD} 4^{+} \mathrm{CD} 25^{+} \mathrm{T}$ cells are 


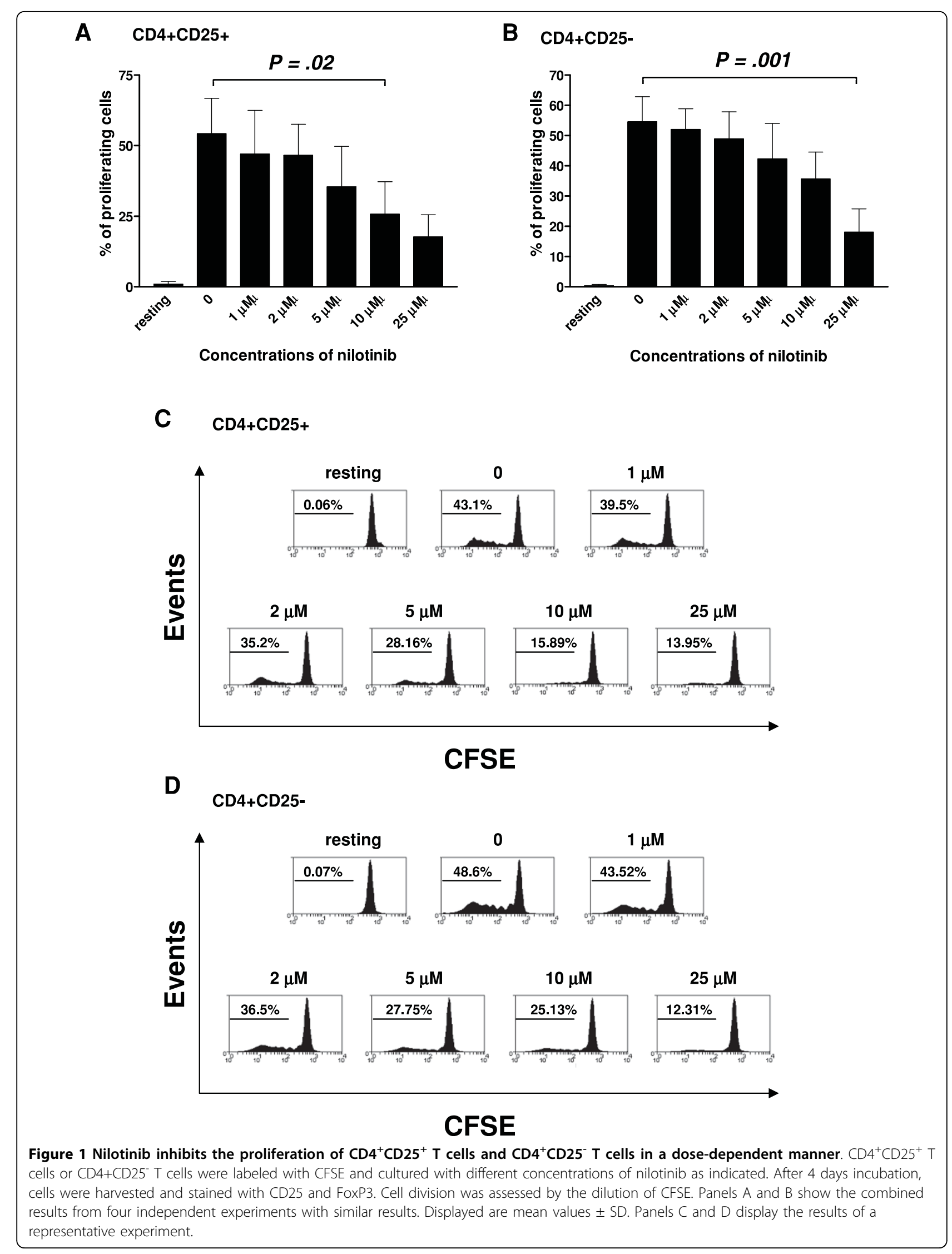




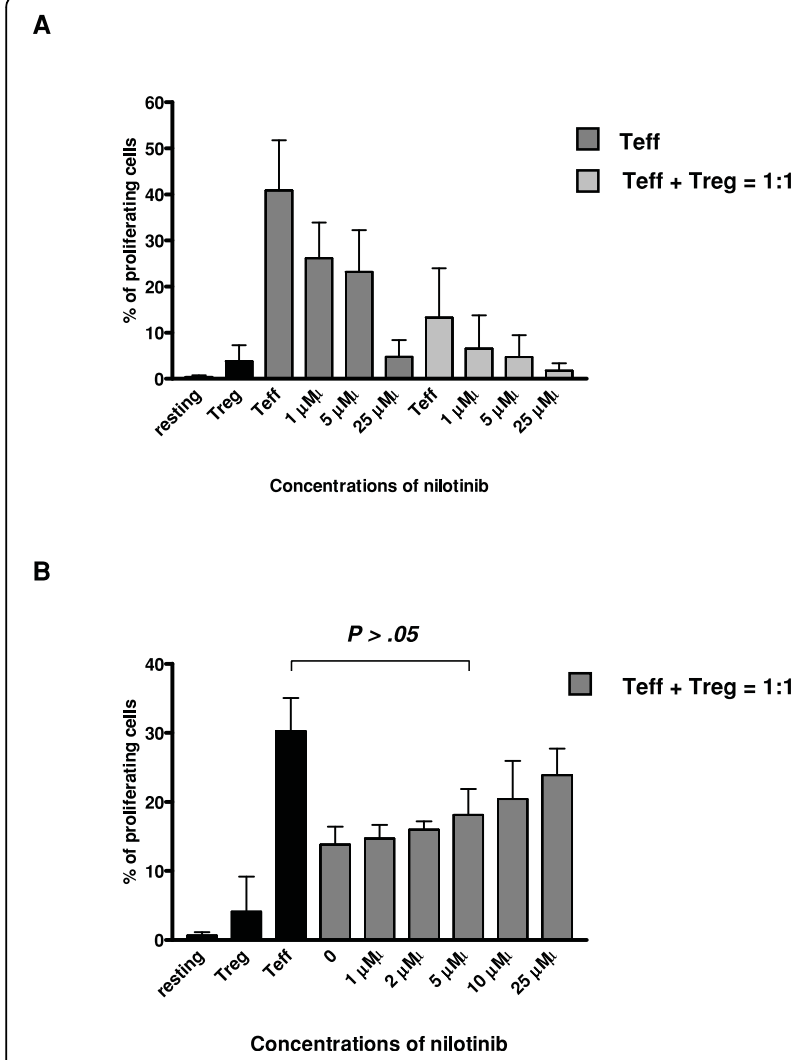

Figure 2 Nilotinib does not hamper immunosuppressive capacity of $\mathrm{CD}^{+} \mathrm{CD}_{25}{ }^{+} \mathrm{T}$ cells at clinical relevant doses. Panel A: Purified $C D 4^{+} C D 25^{+} T$ cells or $C D 4^{+} C D 25^{-} T$ cells (Teff) were labeled with CFSE. CFSE ${ }^{+}$-labeled $\mathrm{CD} 4^{+} \mathrm{CD} 25^{-} \mathrm{T}$ cells were stimulated with anti-CD3 and anti-CD28 in the presence or absence of nilotinib. The proliferation of $\mathrm{CD} 4^{+} \mathrm{CD} 25^{-} \mathrm{T}$ cells was measured by the division of CFSE. Combined results from three independent experiments were shown. Panel B: $\mathrm{CD} 4{ }^{+} \mathrm{CD} 25^{+} \mathrm{T}$ cells were first incubated with different concentrations of nilotinib overnight in the presence of IL-2. After washing cells for three times, $\mathrm{CD} 4^{+} \mathrm{CD} 25^{+} \mathrm{T}$ cells were co-cultured with $\mathrm{CFSE}^{+}$-labeled $\mathrm{CD}^{+}{ }^{+} \mathrm{CD} 25^{-} \mathrm{T}$ cells as a ratio of 1:1. Cell division was assessed by levels of CFSE dilution.

much more sensitive to apoptosis than $\mathrm{CD} 4^{+} \mathrm{CD} 25^{-} \mathrm{T}$ cells in agreement with the characteristics described previously for Tregs [21].

Nilotinib arrests $\mathrm{CD} 4^{+} \mathrm{CD} 25^{+} \mathrm{T}$ cells and $\mathrm{CD} 4^{+} \mathrm{CD} 25^{-} \mathrm{T}$ cells accumulating in the $G_{0} / G_{1}$ phase at high concentrations Since many cytotoxic drugs are effective through inducing cell death, but also by causing an arrest in specific phases of cell cycle, we next examined whether nilotinib had an effect on cell cycle distribution. We stimulated CD $4{ }^{+} \mathrm{CD} 25^{+} \mathrm{T}$ cells or $\mathrm{CD} 4{ }^{+} \mathrm{CD} 25^{-} \mathrm{T}$ cells with antiCD3, anti-CD28 and IL-2 and measured cell cycle distribution by BrdU staining. Anti-CD3 and anti-CD28, in combination with IL-2, stimulated DNA synthesis in both $\mathrm{CD} 4^{+} \mathrm{CD} 25^{+} \mathrm{T}$ cells and $\mathrm{CD} 4^{+} \mathrm{CD} 25^{-} \mathrm{T}$ cells and progressed cells into $\mathrm{S}$ phase, this effect was significantly

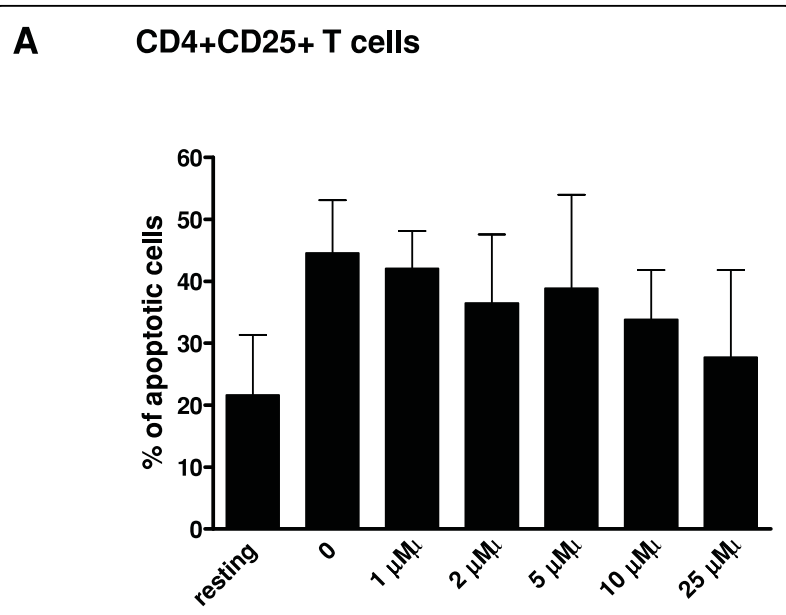

Concentrations of nilotinib

B

CD4+CD25- T cells

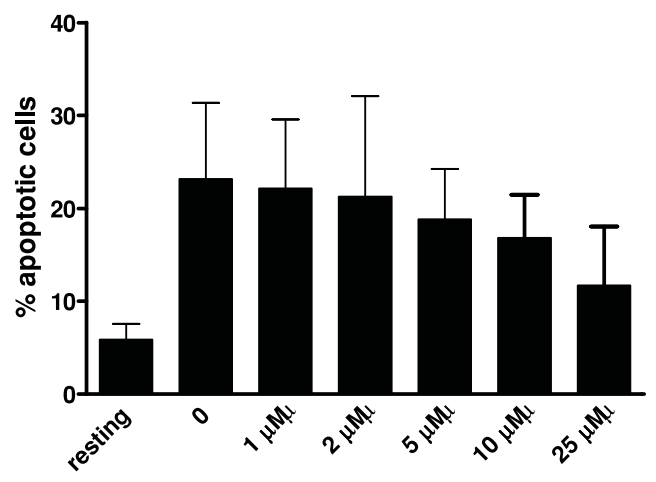

Concentrations of nilotinib

Figure 3 Nilotinib does not induce apoptosis on $\mathrm{CD}^{+} \mathrm{CD}^{2} 5^{+} \mathrm{T}$ cells and $\mathrm{CD}^{+} \mathrm{CD} 25 \mathrm{~T}$ cells. $\mathrm{CD} 4^{+} \mathrm{CD} 25^{+} \mathrm{T}$ cells (Panel A) and CD4 ${ }^{+}$CD25T cells (Panel B) were stimulated with anti-CD3, anti-CD28 and IL-2 with different concentrations of nilotinib as indicated for 48 h. Cells were then harvested and stained with Annexin $V^{*}$ FITC and $\mathrm{Pl}$. Apoptotic cells were defined by flow cytometry as Annexin $\mathrm{V}$ positive and PI negative cells.

inhibited by nilotinib at concentrations $>10 \mu \mathrm{M}$ (data not shown), while nilotinib showed little significant inhibitory effect on cell cycle distribution at concentrations within the therapeutic dose range of the drug.

Nilotinib shows inhibitory effects on cytokine secretion of $\mathrm{CD} 4^{+} \mathrm{CD} 25^{+} \mathrm{T}$ cells and $\mathrm{CD} 4^{+} \mathrm{CD} 25^{-} \mathrm{T}$ cells

Cytokine production and release is a key process by which activated $\mathrm{T}$ cells participate in immune responses; 
A

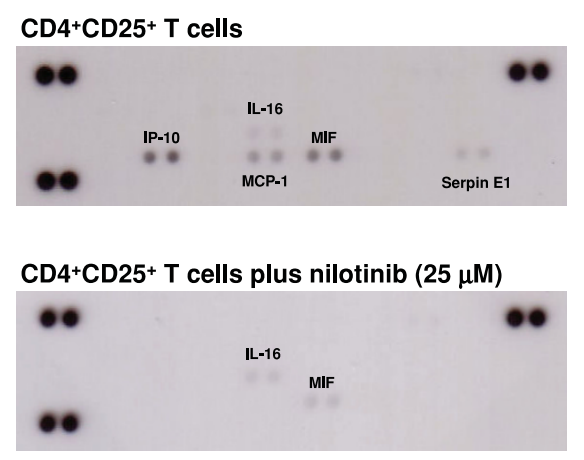

C

CD4+CD25- $T$ cells

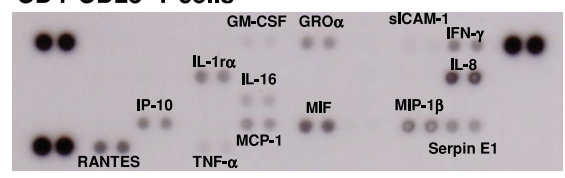

CD4+CD25- T cells plus nilotinib $(25 \mu \mathrm{M})$

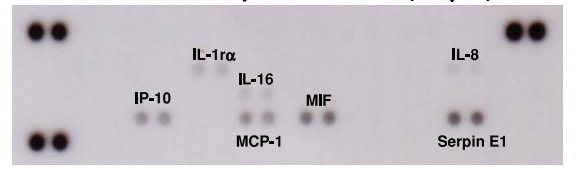

B

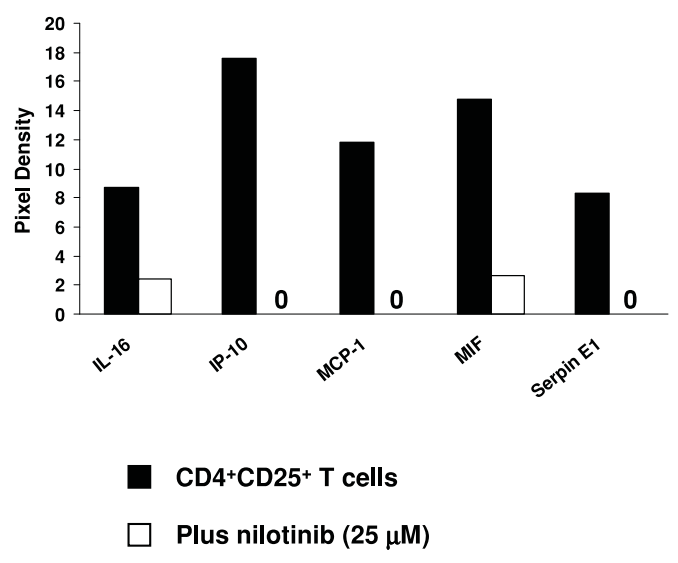

D

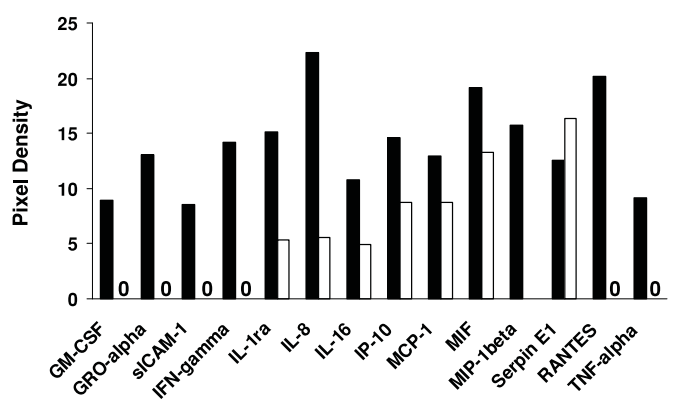

CD4+CD25 $T$ cells

Plus nilotinib $(25 \mu \mathrm{M})$

Figure 4 Nilotinib inhibits the cytokine production by $C D 4^{+} C D 25^{+}$T cells and $C D 4^{+} C D 25^{-} \mathbf{T}$ cells. Panel A: $C D 4^{+} C D 25^{+} T$ cells were stimulated with anti-CD3, anti-CD28 and IL-2 in the presence or absence of $25 \mu \mathrm{M}$ nilotinib. After 4 days incubation, supernatants were collected for cytokine analysis. The high intensity spots in the three corners are positive controls, the lower right contains the negative controls. Panel B: Graphs of the relative density (subtracted the average background signals) are shown for selected cytokines. Array images are shown in panel $\mathrm{A}$ and profiles created by quantifying the background-subtracted mean spot pixel densities are identified as shown in Panel B by using image analysis software. Panel C + D: The cytokine production of $C D 4^{+} \mathrm{CD} 25^{-} \mathrm{T}$ cells treated with nilotinib was analyzed by above methods.

and in situations of aberrant immune activity (autoimmunity, GVHD and transplant rejection) cytokines are involved in the pathophysiologic sequelae [22-24]. CD4 ${ }^{+} \mathrm{CD} 25^{+} \mathrm{T}$ cells and $\mathrm{CD} 4{ }^{+} \mathrm{CD} 25^{-} \mathrm{T}$ cells were stimulated and treated with or without $25 \mu \mathrm{M}$ nilotinib. After 4 days of incubation, supernatants were collected for cytokine analysis (Figure 4). Nilotinib inhibited multiple cytokines production including pro-inflammatory cytokines (TNF- $\alpha$, IFN- $\gamma$, and IL-1r $\alpha$ ) and chemotactic factors (MIP-1 $\beta$, MCP-1, RANTES, IP-10, etc) by CD4 ${ }^{+} \mathrm{CD} 25^{-} \mathrm{T}$ cells at a high concentration of $25 \mu \mathrm{M}$. CD4 ${ }^{+} \mathrm{CD} 25^{+} \mathrm{T}$ cells only secreted few cytokines compared with $\mathrm{CD} 4{ }^{+} \mathrm{CD} 25^{-} \mathrm{T}$ cells (Figure $4 \mathrm{C}$ and $4 \mathrm{D}$ ). $\mathrm{T}$-cell receptor (TCR)-mediated activation Tregs were proved to have very low in vitro proliferative capacity and they do not produce cytokines compared with other $\mathrm{T}$ cells [25]. However, nilotinib inhibits the cytokines production by $\mathrm{CD} 4{ }^{+} \mathrm{CD} 25^{+} \mathrm{T}$ cells significantly at a concentration of $25 \mu \mathrm{M}$.

Nilotinib down-regulates the expression of $\mathrm{CD}^{+} \mathrm{CD} 25^{+} \mathrm{T}$ cell-specific molecules in a dose-dependent manner To investigate the inhibitory effect of nilotinib on the phenotype of $\mathrm{CD} 4{ }^{+} \mathrm{CD} 25^{\text {high }} \mathrm{T}$ cells, $\mathrm{CD} 4^{+} \mathrm{CD} 25^{+} \mathrm{T}$ cells 
A

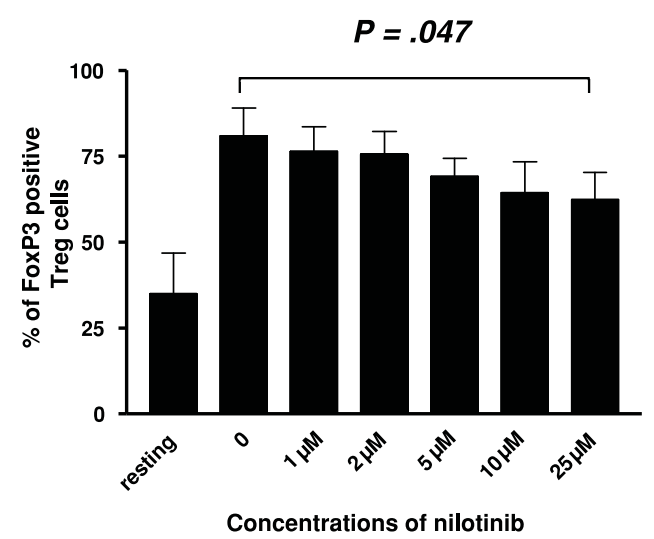

B

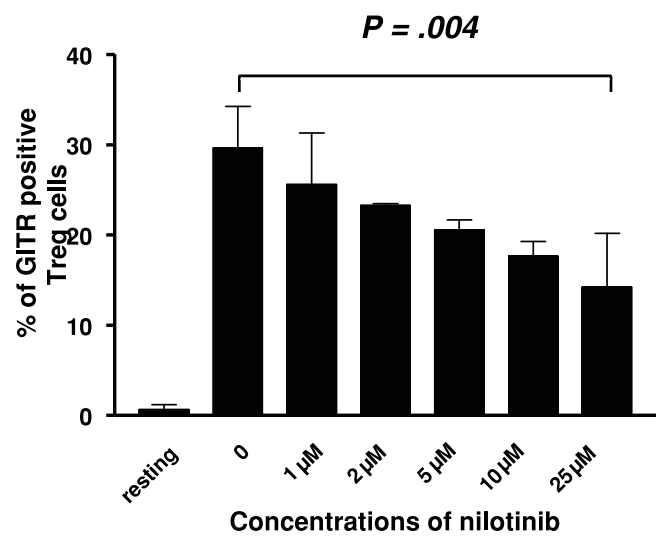

Figure 5 High concentrations of nilotinib down-regulate the expression of FoxP3 and GITR by $\mathrm{CD}^{+}{ }^{+} \mathrm{CD} 25^{+} \mathrm{T}$ cells. Purified $\mathrm{CD} 4^{+} \mathrm{CD} 25^{+} \mathrm{T}$ cells were unstimulated or stimulated with anti-CD3, anti-CD28 and IL-2 in the presence or absence of nilotinib as indicated. Then cells were stained with FoxP3*PE or GITR*PE according to the manufacturer's instruction for fixation, permeabilization, and staining, after cells were stained for surface expression of CD4 and CD25. Nilotinib significantly decreased the intracellular expression of FoxP3 and GITR on $\mathrm{CD}^{+} \mathrm{CD}_{25} 5^{+} \mathrm{T}$ cells in a dose-dependent manner at concentrations of $25 \mu \mathrm{M}$. Data are representative of four independent experiments with similar results. Displayed are mean values \pm SD.

were stimulated with anti-CD3, anti-CD28 and IL-2 for 4 days. After stimulation, the expression of FoxP3 and GITR were up-regulated compared with unstimulated cells. However, nilotinib only at a concentration of 25 $\mu \mathrm{M}$ could down-regulate the expression of FoxP3 (P = $.047)$ and GITR $(\mathrm{P}=.004)$ significantly (Figure 5$)$ which was associated with the data in proliferation assay.

Nilotinib does not show signaling events on TCR in CD4 ${ }^{+} \mathrm{CD} 25^{+} \mathrm{T}$ cells and $\mathrm{CD} 4{ }^{+} \mathrm{CD} 25^{-} \mathrm{T}$ cells

$\mathrm{CD} 4{ }^{+} \mathrm{CD} 25^{+} \mathrm{T}$ cells and $\mathrm{CD} 4^{+} \mathrm{CD} 25^{-} \mathrm{T}$ cells were incubated with or without different concentrations of nilotinib for one hour. After incubation, cells were stimulated with anti-CD3 and anti-CD28 for 15 minutes. Nilotinib did not significantly decrease the levels of pLck and p-ZAP even at a high concentration of $25 \mu \mathrm{M}$ as shown in Figure 6A.

Furthermore, we compared the effects of nilotinib, imatinib and dasatinib on TCR, Src and NF- $\kappa$ B dependent signal cascades in Jurkat $\mathrm{T}$ cells. Figure $6 \mathrm{~B}$ clearly shows that exposure of cells to low nanomolar concentrations of dasatinib attenuated the phosphorylation levels of Lck, ZAP-70, ERK 1/2, AKT, Src Tyr416, Src Tyr527 and NF- $\kappa$ B P65 in a dose-dependent manner. Imatinib only showed significant effects at a dose of 25 $\mu \mathrm{M}$ which is 100 -fold higher concentrations than dasatinib. In contrast, nilotinib showed no significant inhibition of TCR, Src and NF- $\kappa$ B signal events, even at a high concentration of $25 \mu \mathrm{M}$.

\section{Discussion}

The novel, selective Abl inhibitor nilotinib was designed to interact with the ATP-binding site of BCR-ABL with a higher affinity than imatinib. Besides being significantly more potent when compared with imatinib, nilotinib also maintains activity against most of the BCR$\mathrm{ABL}$ point mutants that confer to imatinib resistance. In phase I/II clinical trials administration of nilotinib resulted in cytogenetic and hematologic responses in imatinib-refractory CML patients [2].

Now nilotinib represents an additional therapeutic option for patients with progressive CML [26].

Naturally occurring Tregs represent between $5 \%$ and $10 \%$ of the $\mathrm{CD}^{+} \mathrm{T}$ cell subset in the peripheral blood of healthy volunteers $[27,28]$. Studies of T-cell mediated immunoregulation provide crucial insights into the immune system's task of balancing immunologic selftolerance, while preserving tumor and anti-microbial immunity. Tregs have emerged as key cellular components that mediate this process [9]. In the stem cell transplantation setting, Tregs have proved to be effective in suppressing lethal graft versus host disease (GVHD). Importantly, this suppression does not abrogate the beneficial graft versus tumor (GVT) effect in most murine models. Moreover, in preliminary studies, donor Tregs promote engraftment and enhance immune reconstitution [9]. Recently, patients with CML are treated with nilotinib when the therapy with imatinib failed or caused serious side effects [2]. The same applies to the situation of CML patients after allogeneic stem cell transplantation. Moreover, patients with a history of nilotinib administration before transplantation are likely to be treated again by the drug in the case of a relapse of the disease after allogeneic stem cell transplantation. Therefore, the effect of nilotinib on Treg function needs to be monitored $[9,29]$. 


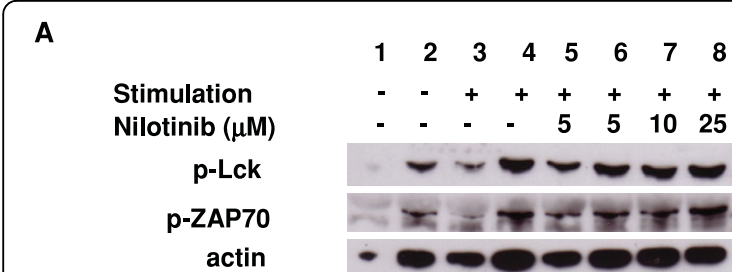

B
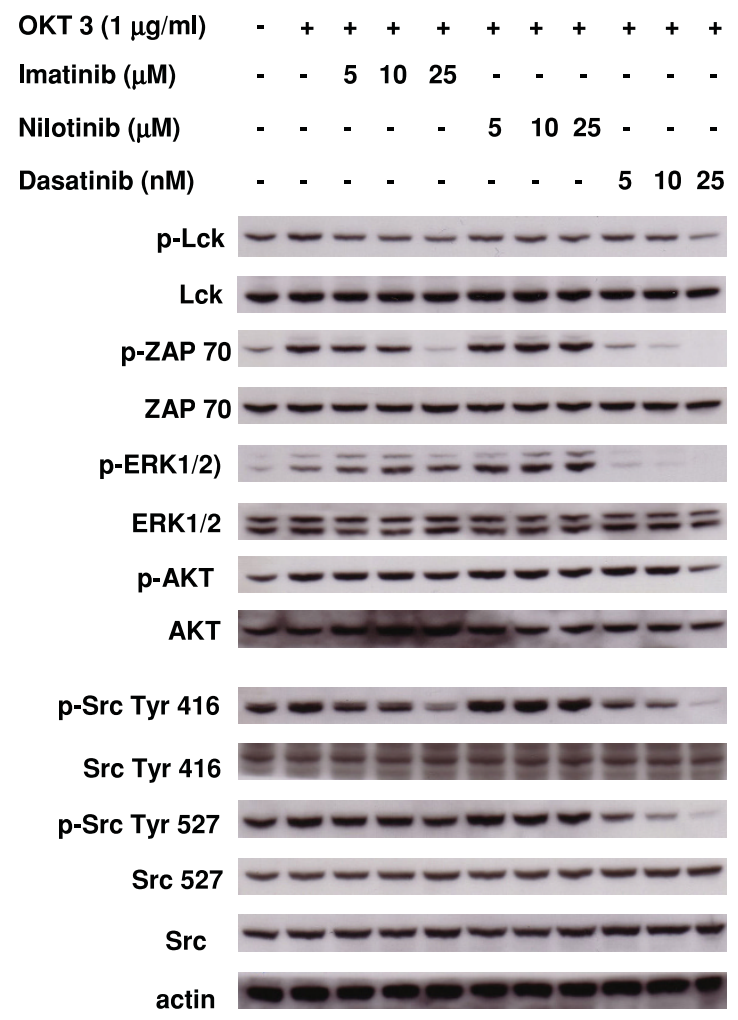

\section{p-NF-kB p65}

NF-kB p65

Figure 6 Nilotinib does not inhibit the signaling events on TCR in $\mathrm{CD}^{+} \mathrm{CD}^{+} 5^{+} \mathrm{T}$ cells and $\mathrm{CD} 4^{+} \mathrm{CD} 25^{-} \mathrm{T}$ cells. Panel $\mathrm{A}$ : Purified $\mathrm{CD} 4^{+} \mathrm{CD} 25^{+} \mathrm{T}$ cells and $\mathrm{CD} 4^{+} \mathrm{CD} 25^{-} \mathrm{T}$ cells were incubated with nilotinib for 1 hour. Then cells were not stimulated or stimulated with anti-CD3/CD28 for 15 minutes. Whole cell lysates were analyzed by western blotting for the phosphorylation levels of Lck and Zap70. (1. non stimulated $\mathrm{CD} 4^{+} \mathrm{CD} 25^{+} \mathrm{T}$ cells; 2 . non stimulated $\mathrm{CD} 4^{+} \mathrm{CD} 25^{-} \mathrm{T}$ cells; 3 . stimulated $\mathrm{CD} 4^{+} \mathrm{CD} 25^{+} \mathrm{T}$ cells; 4 . stimulated $\mathrm{CD}^{+} \mathrm{CD} 25^{-} \mathrm{T}$ cells; 5 . stimulated $\mathrm{CD}^{+} \mathrm{CD}^{+} 5^{+} \mathrm{T}$ cells plus nilotinib; 6 . stimulated $C D 4^{+} C D 25^{-} T$ cells plus nilotinib; 7. stimulated $C D 4^{+} \mathrm{CD} 25$ $\mathrm{T}$ cells plus nilotinib; 8. stimulated $\mathrm{CD} 4^{+} \mathrm{CD} 25^{-} \mathrm{T}$ cells plus nilotinib; the respective concentration of nilotinib is indicated in the figure.) Panel B: Comparison of imatinib, nilotinib and dasatinib on the effects of TCR, Src and NF- $\kappa$ B signaling molecules in the Jurkat cell line. Compared with imatinib and dasatinib, nilotinib did not show obvious inhibitory effects in Jurkat T cells, while dasatinib showed the highest inhibitory potency among the three drugs. Data are representative of three experiments with similar results.
In an effort to investigate the potential role as nilotinib as an immunomodulatory agent, we set our studies on three important parts of $\mathrm{T}$ cell responses: TCR signaling and expression of activation markers, cytokine production, and proliferation [13]. In our study, we observed that therapeutic doses of nilotinib did not hamper the proliferation and function, of either CD4 ${ }^{+} \mathrm{CD} 25^{+} \mathrm{T}$ cells or $\mathrm{CD} 4{ }^{+} \mathrm{CD} 25^{-} \mathrm{T}$ cells. Nilotinib only showed significant inhibitory effect on $\mathrm{CD} 4{ }^{+} \mathrm{CD} 25^{+} \mathrm{T}$ cells or $\mathrm{CD} 4^{+} \mathrm{CD} 25^{-} \mathrm{T}$ cells at a concentration higher than $10 \mu \mathrm{M}$. However, Chen et al showed that nilotinib inhibits phytohemagglutinin (PHA)-induced proliferation of $\mathrm{CD}^{+} \mathrm{T}$ cells in vitro at therapeutically relevant concentrations $(0.5-4 \mu \mathrm{M})$ [16]. Similar results were also shown by Blake et al. [30]. We think the difference between us might be the reason we use anti-CD3, antiCD28 and IL-2 to stimulate $\mathrm{CD} 4{ }^{+} \mathrm{CD} 25^{+} \mathrm{T}$ cells and $\mathrm{CD} 4^{+} \mathrm{CD} 25^{-} \mathrm{T}$ cells which is stronger than PHA that could partly abrogate the inhibitory effect of nilotinib on cells. However, the correlates between nilotinib and $\mathrm{T}$ cells in vivo are still unknown and it is still not clear which assays are more appropriate in gauging the suppressive effect of nilotinib. Furthermore, our results present that nilotinib did not affect the suppressive capacity of Tregs at therapeutically relevant concentrations, only at a concentration of $5 \mu \mathrm{M}$. Tregs and nilotinib act in synergy to reduce $\mathrm{CD} 4^{+} \mathrm{CD} 25^{-} \mathrm{T}$ cells proliferation when co-cultured at the same time. We propose that the reason is that the direct inhibitory effect of nilotinib on $\mathrm{CD} 4^{+} \mathrm{CD} 25^{-} \mathrm{T}$ cells might be stronger than the indirectly inhibitory effect on the proliferation of $\mathrm{CD} 4^{+} \mathrm{CD} 25^{-}$ $\mathrm{T}$ cells by Tregs.

The recent identification of the FoxP3, as a more specific marker of Tregs better defines the regulatory subset of $\mathrm{CD} 4^{+} \mathrm{T}$ cells from activated effector T cells [9]. Based on consistent findings in mice and humans, FoxP3 is considered the "master regulator" of Tregs [9]. GITR is highly and constitutively expressed on the surface of mouse and human Tregs. Stimulation of GITR in vitro or in vivo or the removal of $\mathrm{T}$ cells expressing high levels of GITR leads to autoimmunity in normal mice $[31,32]$. In our study, we observed that high doses of nilotinib down-regulated the expression of FoxP3 and GITR in Tregs in a dose-dependent manner, which was accordance to the function of Tregs.

In the next step, we investigated the signaling events in CD4+CD25+ T cells and CD4+CD25- T cells after treatment with nilotinib. Consistent with previous data, nilotinib did not impair the phosphorylation levels of Lck and ZAP70 in cells even at a high concentration of $25 \mu \mathrm{M}$. Furthermore, we compared the inhibitory effects of imatinib, nilotinib and dasatinib on signal events against Jurkat $\mathrm{T}$ cells. An interesting phenomenon is that imatinib-resistant CML patients who develop resistance against nilotinib 
may still show a response to dasatinib, and patients with resistance against dasatinib may still respond to nilotinib [33]. Another remarkable aspect is that, in contrast to nilotinib, dasatinib exhibits a number of clinically relevant side effects including cytopenia and pleural effusions when applied at approved doses [34]. All these observations point to major differences of the three tyrosine kinase inhibitors regarding their mechanism of action and target profiles in pathological as well as normal cells [33]. We demonstrated that among the three drugs, dasatinib showed the highest potency on TCR, Src and NF- $\kappa$ B signaling events, while nilotinib did not show inhibitory effects on this signaling transduction cascade, which is in accordance with the molecular mechanisms of the three drugs. Previous biochemical studies have already revealed pronounced differences between the three tyrosine kinase inhibitors with regard to their selectivity. Nilotinib, like imatinib, inhibits BCR-ABL, c-ABL, c-KIT, and PDGFR, although with greater potency and selectivity for BCRABL [5]. The selectivity of nilotinib against BCR-ABL (relative to other targets, such as Src-family or c-Kit kinases) may account for the high level of efficacy unaccompanied by higher rates of severe myelosuppression [6]. Dasatinib, on the other hand, has been developed as a dual-specificity Abl- and Src-family kinase inhibitor [35]. Moreover, several pathways of the immune system could be severely affected by continuous high doses of dasatinib, harboring significant risks for immunosuppression of patients treated over a long period of time [33]. Recently, our group shows that imatinib inhibits the proliferation and function of Tregs and $\mathrm{CD}^{+} \mathrm{T}$ cells as a concentration range of $1-5 \mu \mathrm{M}$, while the range for dasatinib is $5-10 \mathrm{nM}$ $[18,36,37]$. Larmonier et al reported that imatinib inhibits the suppressive function and FoxP3 expression on Tregs as low as $1 \mu \mathrm{M}$. In vivo study indicated that imaitnib decreases Treg frequency and impairs their immunosuppressive function for mice treated with imatinib but imatinib does not impair the production of IL-10 and TGF- $\beta$ in vitro [38]. Dasatinib proves to be much more potent than imatinib and nilotinib on Tregs and $\mathrm{CD}^{+} \mathrm{T}$ cells. Chow et al. reported that although nilotinib exhibits only a minor apoptosis-inducing effect in the T-cell lines, it exerts a considerable, dose-dependent cytotoxicity in the $\mathrm{B}$-cell lines. The activity of nilotinib is not restricted to Bcr-Abl, c-kit, or PDGFR-positive cells, but also extends to lymphatic cell lines of B-cell origin at a concentration of $5 \mu \mathrm{M}$ [39]. Furthermore, Hipp et al. indicated that the multitargeted tyrosine serine/threonine kinase inhibitor sunitinib could significantly decrease the number of Tregs in the peripheral blood of mice treated with subtoxic doses of the drug, but does not show an impaired $\mathrm{CD}^{+} \mathrm{T}$ cell response [40]. As all these compounds have already entered clinical practice, it would be useful to further define the appropriate clinical angle, because it would allow a rational approach to balance effector $\mathrm{T}$ cells and Tregs especially for patients after allogeneic stem cell transplantation.

In conclusion, our results show that the tyrosine kinase inhibitor nilotinib can inhibit both proliferation and function of Tregs and $\mathrm{CD} 4^{+} \mathrm{CD} 25^{-} \mathrm{T}$ cells only at high concentrations, which exceeds therapeutically relevant concentrations of the drug. Since nilotinib has less inhibitory effects on Tregs than imatinib and dasatinib, nilotinib might constitute a good choice for patients in transplantation settings.

\section{Acknowledgements}

Novartis kindly supported this research.

\section{Author details}

${ }^{1}$ Department of Internal Medicine III, University of Ulm, 89081 UIm, Germany. ${ }^{2}$ Institute for Transfusion Medicine, University of Ulm, and Institute for Clinical Transfusion Medicine and Immunogenetics Ulm gemeinnuetzige GmbH, 89081 Ulm, Germany. ${ }^{3}$ Department of Hematology and Oncology, ZhongDa Hospital, Southeast University, Nanjing 210009, PR China. ${ }^{4}$ Current address: Center for Internal Medicine, Medical Clinic III - Department of Hematology, Oncology, Palliative Medicine, University of Rostock, ErnstHeydemann-Str 6, 18057 Rostock, Germany.

\section{Authors' contributions}

FF carried out the molecular biology studies, participated in the sequence alignment and drafted the manuscript and carried out the immunoassays, YY carried out analysis the immunoassays and drafted the manuscript, AS participated in the design of the study, MTR carried out FACS, BC participated in the design of the study, JG participated in the design of the study, MG participated in the sequence alignment and helped to draft the manuscript, DB participated in its design and coordination and helped to draft the manuscript and MS conceived of the study, and participated in its design and coordination and finalized the manuscript. All authors read and approved the final manuscript.

\section{Competing interests}

The authors declare that they have no competing interests.

Received: 30 July 2009

Accepted: 29 January 2010 Published: 29 January 2010

\section{References}

1. Golemovic M, Verstovsek S, Giles F, Cortes J, Manshouri T, Manley PW, Mestan J, Dugan M, Alland L, Griffin JD, Arlinghaus RB, Sun T, Kantarjian H, Beran M: AMN107, a novel aminopyrimidine inhibitor of Bcr-Abl, has in vitro activity against imatinib-resistant chronic myeloid leukemia. Clin Cancer Res 2005, 11:4941-7.

2. Kantarjian H, Giles F, Wunderle L, Bhalla K, O'Brien S, Wassmann B, Tanaka C, Manley P, Rae P, Mietlowski W, Bochinski K, Hochhaus A, Griffin JD, Hoelzer D, Albitar M, Dugan M, Cortes J, Alland L, Ottmann OG: Nilotinib in imatinib-resistant CML and Philadelphia chromosome-positive ALL. N Engl J Med 2006, 354:2542-51.

3. O'Hare T, Walters DK, Stoffregen EP, Jia T, Manley PW, Mestan J, CowanJacob SW, Lee FY, Heinrich MC, Deininger MW, Druker BJ: In vitro activity of Bcr-Abl inhibitors AMN107 and BMS-354825 against clinically relevant imatinib-resistant Abl kinase domain mutants. Cancer Res 2005, 65:4500-5.

4. Verstovsek S, Golemovic M, Kantarjian H, Manshouri T, Estrov Z, Manley P. Sun T, Arlinghaus RB, Alland L, Dugan M, Cortes J, Giles F, Beran M: AMN107, a novel aminopyrimidine inhibitor of p190 Bcr-Abl activation and of in vitro proliferation of Philadelphia-positive acute lymphoblastic leukemia cells. Cancer 2005, 104:1230-6.

5. Weisberg E, Manley PW, Breitenstein W, Brüggen J, Cowan-Jacob SW, Ray A Huntly B, Fabbro D, Fendrich G, Hall-Meyers E, Kung AL, Mestan J, Daley GQ, Callahan L, Catley L, Cavazza C, Azam M, Neuberg D, Wright RD, 
Gilliland DG, Griffin JD: Characterization of AMN107, a selective inhibitor of native and mutant Bcr-Abl. Cancer Cell 2005, 7:129-41.

6. Kantarjian HM, Giles F, Gattermann N, Bhalla K, Alimena G, Palandri F, Ossenkoppele GJ, Nicolini FE, O'Brien SG, Litzow M, Bhatia R, Cervantes F, Haque A, Shou Y, Resta DJ, Weitzman A, Hochhaus A, le Coutre P: Nilotinib (formerly AMN107), a highly selective BCR-ABL tyrosine kinase inhibitor, is effective in patients with Philadelphia chromosome-positive chronic myelogenous leukemia in chronic phase following imatinib resistance and intolerance. Blood 2007, 110:3540-6.

7. le Coutre P, Ottmann OG, Giles F, Kim DW, Cortes J, Gattermann N, Apperley JF, Larson RA, Abruzzese E, O'Brien SG, Kuliczkowski K, Hochhaus A, Mahon FX, Saglio G, Gobbi M, Kwong YL, Baccarani M, Hughes T, Martinelli G, Radich JP, Zheng M, Shou Y, Kantarjian H: Nilotinib (formerly AMN107), a highly selective BCR-ABL tyrosine kinase inhibitor, is active in patients with imatinib-resistant or -intolerant acceleratedphase chronic myelogenous leukemia. Blood 2008, 111:1834-9.

8. Tojo A, Usuki K, Urabe A, Maeda Y, Kobayashi Y, Jinnai I, Ohyashiki K, Nishimura M, Kawaguchi T, Tanaka H, Miyamura K, Miyazaki Y, Hughes T, Branford S, Okamoto S, Ishikawa J, Okada M, Usui N, Tanii H, Amagasaki T, Natori H, Naoe T: A Phase I/II study of nilotinib in Japanese patients with imatinib-resistant or -intolerant $\mathrm{Ph}+\mathrm{CML}$ or relapsed/refractory $\mathrm{Ph}+\mathrm{ALL}$. Int J Hematol 2009, 89:679-88,

9. Nguyen VH, Zeiser R, Negrin RS: Role of naturally arising regulatory T cells in hematopoietic cell transplantation. Biol Blood Marrow Transplant 2006, 12:995-1009.

10. Tao $R$, Hancock $W W$ : Regulating regulatory $T$ cells to achieve transplant tolerance. Hepatobiliary Pancreat Dis Int 2007, 6:348-57.

11. Cwynarski K, Laylor R, Macchiarulo E, Goldman J, Lombardi G, Melo JV, Dazzi F: Imatinib inhibits the activation and proliferation of normal T lymphocytes in vitro. Leukemia 2004, 18:1332-9.

12. Dietz $A B$, Souan L, Knutson GJ, Bulur PA, Litzow MR, Vuk-Pavlovic S: Imatinib mesylate inhibits T-cell proliferation in vitro and delayed-type hypersensitivity in vivo. Blood 2004, 104:1094-9.

13. Schade AE, Schieven GL, Townsend R, Jankowska AM, Susulic V, Zhang R, Szpurka $H$, Maciejewski JP: Dasatinib, a small-molecule protein tyrosine kinase inhibitor, inhibits T-cell activation and proliferation. Blood 2008, 111:1366-77.

14. Seggewiss $R$, Loré $K$, Greiner E, Magnusson MK, Price DA, Douek DC, Dunbar CE, Wiestner A: Imatinib inhibits T-cell receptor-mediated T-cell proliferation and activation in a dose-dependent manner. Blood 2005, 105:2473-9.

15. Weichsel R, Dix C, Wooldridge L, Clement M, Fenton-May A, Sewell AK, Zezula J, Greiner E, Gostick E, Price DA, Einsele H, Seggewiss R: Profound inhibition of antigen-specific T-cell effector functions by dasatinib. Clin Cancer Res 2008, 14:2484-91.

16. Chen J, Schmitt A, Chen B, Rojewski M, Rübeler V, Fei F, Yu Y, Yu X, Ringhoffer M, von Harsdorf S, Greiner J, Götzz M, Guillaume P, Döhner H, Bunjes D, Schmitt M: Nilotinib hampers the proliferation and function of CD8+ T lymphocytes through inhibition of T cell receptor signalling. J Cell Mol Med 2008, 12:2107-18.

17. Mustjoki S, Ekblom M, Arstila TP, Dybedal I, Epling-Burnette PK, Guilhot F, Hjorth-Hansen H, Höglund M, Kovanen P, Laurinolli T, Liesveld J, Paquette R, Pinilla-lbarz J, Rauhala A, Shah N, Simonsson B, Sinisalo M, Steegmann JL, Stenke L, Porkka K: Clonal expansion of T/NK-cells during tyrosine kinase inhibitor dasatinib therapy. Leukemia 2009, 23:1398-405.

18. Fei F, Yu Y, Schmitt A, Rojewski MT, Chen B, Greiner J, Götz M, Guillaume P, Döhner H, Bunjes D, Schmitt M: Dasatinib exerts an immunosuppressive effect on CD8+ T cells specific for viral and leukemia antigens. Exp Hematol 2008, 36:1297-308

19. Hoffmann $P$, Eder R, Kunz-Schughart LA, Andreesen R, Edinger M: Largescale in vitro expansion of polyclonal human $\mathrm{CD} 4(+) \mathrm{CD} 25$ high regulatory T cells. Blood 2004, 104:895-903.

20. Li L, Godfrey WR, Porter SB, Ge Y, June CH, Blazar BR, Boussiotis VA: CD4 $+\mathrm{CD} 25+$ regulatory $\mathrm{T}$-cell lines from human cord blood have functional and molecular properties of T-cell anergy. Blood 2005, 106:3068-73.

21. Yolcu ES, Ash S, Kaminitz A, Sagiv Y, Askenasy N, Yarkoni S: Apoptosis as a mechanism of T-regulatory cell homeostasis and suppression. Immunol Cell Biol 2008, 86:650-8.

22. Choy EH, Panayi GS: Cytokine pathways and joint inflammation in rheumatoid arthritis. N Engl J Med 2001, 344:907-16.
23. Ferrara JL, Reddy P: Pathophysiology of graft-versus-host disease. Semin Hematol 2006, 43:3-10.

24. Walsh PT, Strom TB, Turka LA: Routes to transplant tolerance versus rejection; the role of cytokines. Immunity 2004, 20:121-31.

25. Bacchetta R, Gambineri E, Roncarolo MG: Role of regulatory T cells and FOXP3 in human diseases. J Allergy Clin Immunol 2007, 120:227-35.

26. Deremer DL, Ustun C, Natarajan K: Nilotinib: a second-generation tyrosine kinase inhibitor for the treatment of chronic myelogenous leukemia. Clin Ther 2008, 30:1956-75.

27. Bluestone JA, Abbas AK: Natural versus adaptive regulatory $T$ cells. Nat Rev Immunol 2003, 3:253-7.

28. Sakaguchi S, Ono M, Setoguchi R, Yagi H, Hori S, Fehervari Z, Shimizu J, Takahashi T, Nomura T: Foxp3+ CD25+ CD4+ natural regulatory T cells in dominant self-tolerance and autoimmune disease. Immunol Rev 2006, 212:8-27.

29. Jabbour E, Cortes JE, Giles FJ, O'Brien S, Kantarijian HM: Current and emerging treatment options in chronic myeloid leukemia. Cancer 2007, 109:2171-81.

30. Blake SJ, Lyons AB, Hughes TP: Nilotinib inhibits the Src-family kinase LCK and T-cell function in vitro. J Cell Mol Med 2009, 13:599-601.

31. McHugh RS, Whitters MJ, Piccirillo CA, Young DA, Shevach EM, Collins M, Byrne MC: CD4(+)CD25(+) immunoregulatory T cells: gene expression analysis reveals a functional role for the glucocorticoid-induced TNF receptor. Immunity 2002, 16:311-23.

32. Shimizu J, Yamazaki S, Takahashi T, Ishida Y, Sakaguchi S: Stimulation of CD25(+)CD4(+) regulatory T cells through GITR breaks immunological self-tolerance. Nat Immunol 2002, 3:135-42.

33. Rix U, Hantschel O, Dürnberger G, Remsing Rix LL, Planyavsky M, Fernbach NV, Kaupe I, Bennett KL, Valent P, Colinge J, Köcher T, SupertiFurga G: Chemical proteomic profiles of the BCR-ABL inhibitors imatinib, nilotinib, and dasatinib reveal novel kinase and nonkinase targets. Blood 2007, 110:4055-63.

34. Talpaz M, Shah NP, Kantarjian H, Donato N, Nicoll J, Paquette R, Cortes J, O'Brien S, Nicaise C, Bleickardt E, Blackwood-Chirchir MA, Iyer V, Chen TT, Huang F, Decillis AP, Sawyers CL: Dasatinib in imatinib-resistant Philadelphia chromosome-positive leukemias. N Engl J Med 2006, 354:2531-41.

35. Lombardo L, Lee FY, Chen P, Norris D, Barrish JC, Behnia K, Castaneda S, Cornelius LA, Das J, Doweyko AM, Fairchild C, Hunt JT, Inigo I, Johnston K, Kamath A, Kan D, Klei H, Marathe P, Pang S, Peterson R, Pitt S, Schieven GL, Schmidt RJ, Tokarski J, Wen ML, Wityak J, Borzilleri RM: Discovery of N-(2chloro-6-methyl-phenyl)-2-(6-(4-(2-hydroxyethyl)- piperazin-1-yl)-2methylpyrimidin-4-yl-amino)thiazole-5-carboxamide (BMS-354825), a dual Src/Abl kinase inhibitor with potent antitumor activity in preclinical assays. J Med Chem 2004, 47:6658-61.

36. Chen J, Schmitt A, Chen B, Rojewski M, Ringhoffer M, von Harsdorf S, Greiner J, Guillaume P, Döhner H, Bunjes D, Schmitt M: Imatinib impairs CD8+ T lymphocytes specifically directed against the leukemiaassociated antigen RHAMM/CD168 in vitro. Cancer Immunol Immunother 2007, 56:849-61.

37. Chen J, Schmitt A, Giannopoulos K, Chen B, Rojewski M, Döhner H, Bunjes D, Schmitt M: Imatinib impairs the proliferation and function of CD4+CD25+ regulatory T cells in a dose-dependent manner. Int J Oncol 2007, 31:1133-9.

38. Larmonier N, Janikashvili N, LaCasse CJ, Larmonier CB, Cantrell J, Situ E, Lundeen T, Bonnotte B, Katsanis E: Imatinib mesylate inhibits CD4+ CD25 + regulatory $T$ cell activity and enhances active immunotherapy against BCR-ABL- tumors. J Immunol 2008, 181:6955-63.

39. Chow KU, Nowak D, Trepohl B, Hochmuth S, Schneider B, Hoelzer D, Mitrou PS, Bergmann L, Ottmann OG, Boehrer S: The tyrosine kinase inhibitor AMN107 (Nilotinib) exhibits off-target effects in lymphoblastic cell lines. Leuk Lymphoma 2007, 48:1379-88.

40. Hipp MM, Hilf N, Walter S, Werth D, Brauer KM, Radsak MP, Weinschenk T, Singh-Jasuja $H$, Brossart P: Sorafenib, but not sunitinib, affects function of dendritic cells and induction of primary immune responses. Blood 2008, 111:5610-20.

doi:10.1186/1476-4598-9-22

Cite this article as: Fei et al:: Effects of nilotinib on regulatory $T$ cells: the dose matters. Molecular Cancer 2010 9:22. 